\title{
Investigations on the aftershock sequence of the great Assam earthquake of August 15, 1950
}

\author{
R. K. S. Chothax $(*)-$ V. K. Gaur $(* *)-$ J. Singh $(*)$
}

Received on April 10th, 1974

\begin{abstract}
SUmmary. - The strain release curve of the aftershock sequence of the great Assam earthquake of August 15, 1950 exhibits three linear segments. A secondary aftershock sequence has also been reported; the strain release curve in this case is also linear. The $b$ value, using the maximum likelihood method of Utsu, for the sequence is $0.52 \pm 0.095$. The fault plane solution shows that the fault strikes almost east-west and dips northward at an angle of $80^{\circ}$; the motion is predominently strike slip (right lateral type). The spatial distribution of aftershocks shows two main centers of activity at the two ends of the probable fault.
\end{abstract}

Riassunto. - La curva dell'energia sismica liberata durante la sequenza di repliche del forte terremoto di Assam (15 Agosto 1950), mostra tre segmenti lineari. È stata anche riportata una sequenza secondaria di repliche; anche in questo caso la curva dell'energia sismica liberata è lineare. Il valore di $b$ per la sequenza, facendo uso del metodo della massima probabilità di Utsu, è risultato di $0.52 \pm 0.095$. La soluzione del piano di faglia, mostra che la faglia si estende pressocché in direzione Est-Ovest e piega verso Nord con un angolo di $80^{\circ}$; il movimento e prevalentemente di scivolamento. La distribuzione spaziale delle repliche mostra due centri principali di attività alle due estremità della probabile faglia.

(*) Department of Applied Geophysies, Indian School of Mines, Dhanbad, Bihar, India.

(**) Department of Geology and Geophysies, University of Roorkee, Roorkee, U.P., India. 


\section{IXTRODLCTION}

On August 15,1950 at 14:09.5 GMT an earthquake of Richter magniturle $8.7^{(21)}$ having the epicenter at $28.6^{\circ} \mathrm{N}, 96.5^{\circ} \mathrm{E}$ occurred in upper Assam. The focal depth of this shock was estimated to be about $15 \mathrm{~km}$. Effects of this earthquake in Assam are given in cletail in a publication of the Central Board of Geophysics $\left.{ }^{20}\right)$. When this earthquake occurred one of the authors was in Myitkyina in a town of northern Burma. An earthquake sound in Myitkyina was heard, coming from the north, and the next morning it was found that the clear water of the river Irrawaddy became muddy. This was due to heavy landslicles in the north at a distance of about $60 \mathrm{kms}$ from Myitkyina, which is the place of origin of the Irrawaddy river where its two tributaries Mekha and Malikha meet. The river in Myitkyina continued to be muldy till April, 1956; after that the author had no information. This implies a considerable amount of landslides in northern Burma, but not in the main town Myitkyina (R.F. Scale VI).

According to one observer in Digboi, two flashes of light were seen to the north which were not due to lightning. This pre-earthquake lightning was perhaps due to stress experienced by the quartz rocks before an earthquake which may produce as much as 500 million volts at a distance of the order of a seismic wavelength, as reported by the U.S. Geological Survey. Such quake-lightning was also observed in Japan, Tashkent and Brazil earthquakes, respectively.

In the twentieth century Assam and its neighbourhood have experienced 40 earthquakes of Richter magnitude $\geqslant 6$. The northeastern part of Assam (the Sadiya region) and the southwestern part of Assam (the Dhubri region) including the Surma valley, are seismically most active $\left({ }^{9}\right)$. Each region experienced an earthquake of Richter magnitude 8.7 in the last century. Banerjee $\left(^{3}\right)$ has given a list of 27 earthquakes which occurred in and around Assam since 1737 with accelerations $\geqslant 90 \mathrm{~cm} / \mathrm{sec}^{2}$ at the epicenter.

\section{Observational Data}

All the magnitude of the aftershocks as reported in the International Seismological Summary and those determined by Tandon (29) have been used in the present study ( $\Lambda$ ppendix 1 ). 
Tandon (29) determined the magnitudes of the aftershocks using the maximum trace amplitude, recorded by standard Wood-Anderson seismographs at Chatra, New Delhi and Poona. The Poona seismological observatory has been given maximum weight because that observatory was equipped with the then modern seismographs, such as a Benioff vertical seismograph and a Sprengnether electromagnetic seismograph, along with Milne-Shaw and torsion seismographs. Whenever there were two horizontal components, the magnitude has been calculated with the help of both, and an average taken. Finally, an average of the various values determined by different stations has been taken. Magnitudes of aftershocks calculated in this way are found to be higher by 0.5 to 1 unit than those estimated by European seismological stations for some of the aftershocks. Magnitude values determined using the Milne-Shaw records were consistently smaller.

\section{Straix Release.}

In calculating a quantity proportional to strain, Benioff's method ( $\left.{ }^{7}\right)$ has been used. Benioff has shown that the strain is proportional to $J^{1 / 2}$, where $J$ is energy (in ergs) released in an earthquake. For the present study this energy has been computed from the magnitude $M$ using the relations ${ }^{(21)}$;

or

$$
\log _{10} J=11.4+1.5 \quad M
$$

$$
\log _{10} J^{1 / 2}=5.7+0.75 M
$$

The relation between $J$ and $M$ has been subjected to several revisions, but here we are much more concerned with the time variation of $\Sigma J^{1 / 2}$ rather than its absolute value. We use formula [2], where the coefficient of $M$ is 0.75 . The inevitable error involved in the determination of magnitude will not materially change the result.

Fig. 1 shows a plot of $\Sigma J^{1 / 2}$ against logt, $t$ being time in days counted from the time of origin of the main shock, which is taken as August 15, at $14^{\mathrm{n}} 09^{\mathrm{m}} 30^{\mathrm{s}}$ GIIT. The straight lines in this figure indicate the mean rate of strain release. These lines are drawn slightly to the left of the plotted points so as not to interfere with them. The figure shows three linear segments, each of which can be represented by an equation of the form

$$
S=\Sigma J^{1 / 2}=A+B \log t
$$




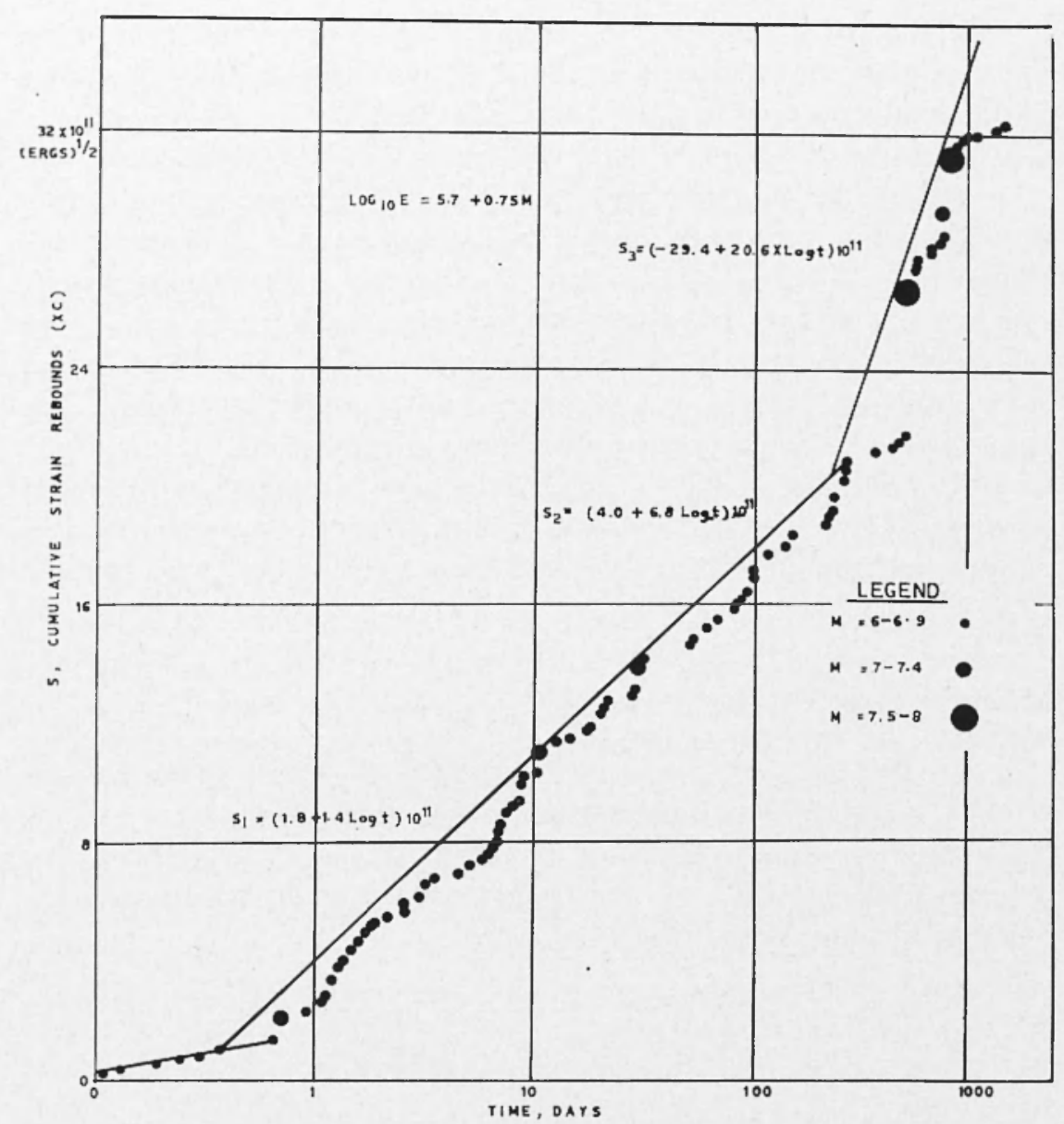

Fig. 1 - Strain release characteristics of the aftershock sequence for all shocks with $I \geqslant 6$.

where $A$ and $B$ are constants. The following values of $B$ have been obtained in the present case

$$
\begin{array}{lc}
t \text { (in lays) } & B \text { (in ergs) })^{1 / 2} \cdot 10^{10} \\
\text { 1. } 0.0 \text { to } 0.72 & 14 \\
\text { 2. } 0.72 \text { to } 310 & 68 \\
3 .>310 & 206
\end{array}
$$

The values of $B$ obtained in this case are not in the ratio of $1: 2: 5$ as observed by Benioft ( ${ }^{7}$ ) and Bath and Benioff ( ${ }^{5}$ ). This is because the $B$ values for the first segment is very low, as a result of which 
the ratio in the present case appears to be 1:5:15. This is because the first listed aftershock in the sequence occurred at $t=0.111$ days, i.e., $2^{\mathrm{n}} 39^{\mathrm{m}} 50^{\mathrm{s}}$ after the main shock. This explains the lower values of $B$ for the first segment, which should have been about $40 \cdot 10^{10}$ $(\mathrm{ergs})^{1 / 2}$ instead of $14 \cdot 10^{10}$ (ergs) $)^{1 / 2}$, to get the result arrived at by Bath and Benioff (5).

Jet us consider the time distribution of magnitude as shown in fig. 2 with time of occurrence of the aftershocks. This figure shows very few shocks in the beginning. However, the first aftershock for this sequence was reported by Corps $\left({ }^{20}\right)$ within two minutes of occurrence of the main shock. Further in the next 24 hours following the main shock the total number of aftershocks reported was 144 out of which 74 aftershocks were felt at Digboi. This means that many of the aftershocks in the beginning could not be detected. In this connection it is worthwhile mentioning that due to violence of the main shock only the preliminary phases and the beginning of the secondary phases could be recorded at most of the Indian observatories. The surface waves, which are the largest in amplitude and which are mainly responsible for causing damage at places away from the epicenter could not be recorded by any of the sensitive seismographs; even the Poona observatory failed to record these events because the recording light spot was completely thrown off the recording camera as soon as the secondary phases arrived.

Fig. 2 clearly shows that the number of larger aftershocks having $M \geqslant 7$ is 6 , and most of them occurred after 100 days from the main

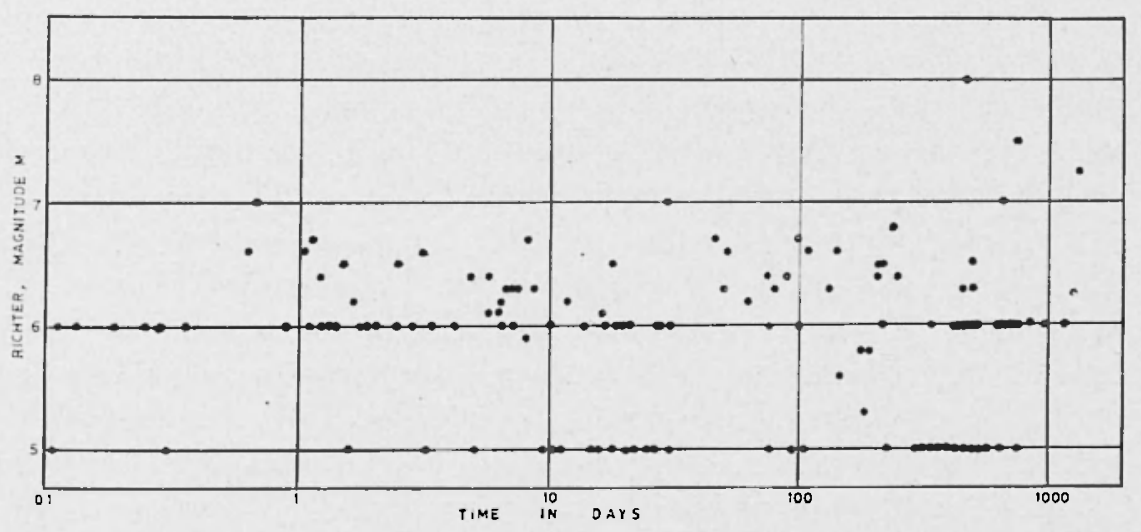

Fig. 2 - Distribution of magnitudes of aftershocks in time starting from the ' $O$ ' time of the main shock. 
shork. The largest recorded magnitude in this sequence is 8.0, which can be taken as a late large aftershock as named by Richter (21). This aftershock was followed by late large aftershocks having magnitudes 7.25 , thus bringing the aftershock activity to the level of local background seismieity.

Several of the larger aftershocks have their own series. Some such aftershocks were usually included in the main sequence, since it would be impossible to distinguish between the primary and the secondary aftershocks. But the large aftershocks, which dlominate the main strain release curve, are primary aftershocks.

The larger aftershock of the Assam earthquake, which had a Richter magnitude 8.0, occurred on November 18, 1951. This was a late large aftershock, occurring after the aftershock activity had apparently subsider. Richter defined some general characteristics for such late large aftershocks.

1) Epicentres of the main shock are normally situated at one end of the active fault segment.

2) Epicentres of large aftershocks are in general situater at the other end of the active fault segment, or at the epicenter of the main shock.

3) $\Delta$ ftershocks are most numerous at the two ends of the active fault segment.

4) Strain release in a sequence is maximum either at the center or at the two ends of the active fault segment.

Because this was a late large aftershock, which occurred when the aftershock activity had apparently subsided, it gives an opportunity to study the secondary aftershock sequence. A large aftershock may be closely followerl by a train of small ones falling off more rapidly than the general aftershock sequence. The occurrence of second-order aftershocks suggests that the larger aftershock with which they are associated is to some extent a new event, dynamically independent of the main shock at the hear of the series. The distinction of the primary and secondary aftershocks can be marle by setting up a scatter plot and comparing the locations of immedliately successive shocks of the series. Following this irlea, the accumulaterl strain rebound increments of the secondary aftershock sequence have been plotted and shown in fig. 3 . This plot also shows a single segment of recovery similar to the main sequence. All the secondary after- 


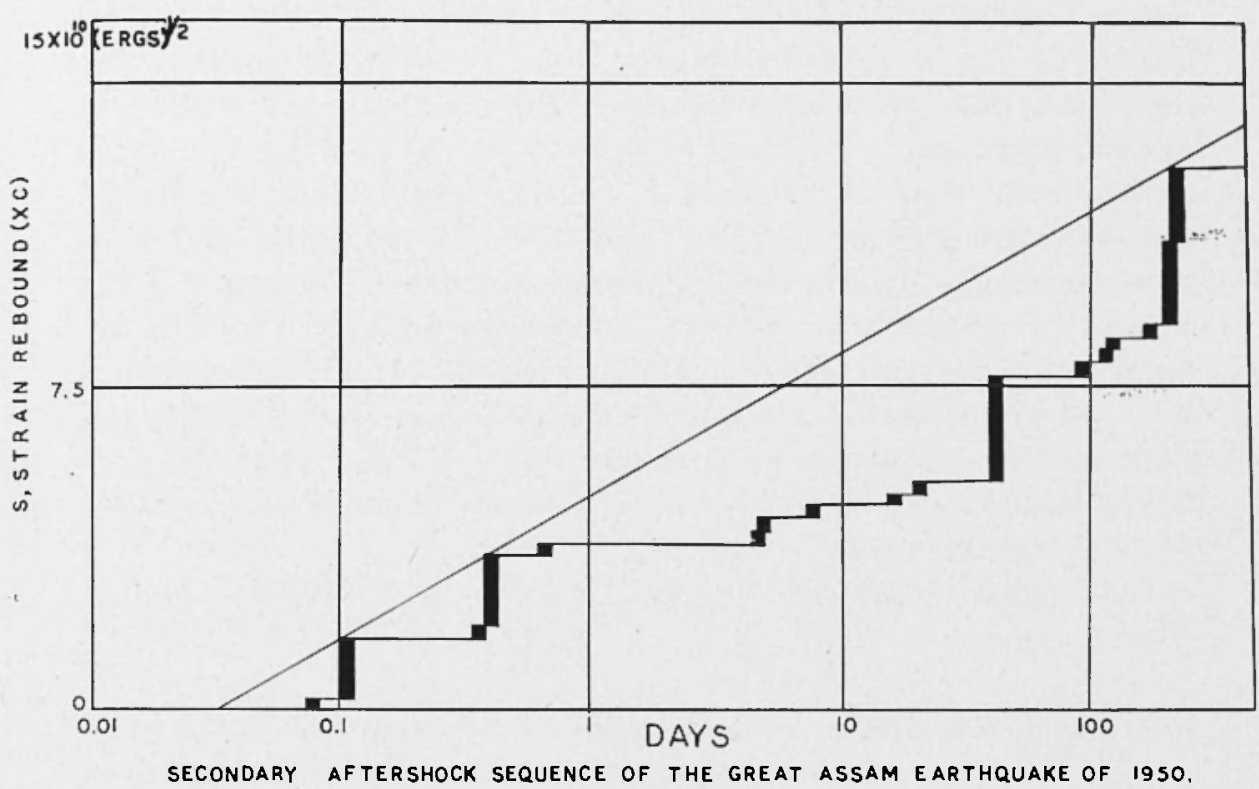

Fig. 3 - Strain release characteristics of the secondary aftershock sequence, of the largest aftershock which occurred on November, 18, 1951, using all secondary aftershocks with $M \geqslant 5$.

shocks used in this plot had $M \geqslant 5$ and are listed in Appendix I, where all the magnitude values preceding SA are secondary aftershocks.

\section{TIME Distribution OF AFterhshocks}

Utsu ( $\left.{ }^{31}\right)$ has found that in most cases the frequency of aftershocks greater than a certain assigned magnitude is empirically expressed by

$$
n(t)=A^{\prime} /(t+c)^{p}
$$

where $t$ is the time measured from the main shock, $n(t)$ is the number of shocks per unit time and $A^{\prime}, c$ and $p$ are characteristics of each case.

According to Utsu $p$ ranges mostly from 1.0 to $1.3, p=1$ corresponding to Omori's hyperbolic formula of aftershocks. Page (18) reported practical difficulty in estimating $c$, which is sensitive to the occurrence of aftershocks in the beginning of the sequence when small 
shocks are likely to be obscured by larger ones. During this time too few shocks are counted and the decay of activity appears to be slower than it is in the later sequence. Such bias learls to a value of $e$ greater than zero.

Corps $\left({ }^{20}\right)$ reported a list of aftershocks recorded at Tinsukia by observers during August 15 to 23,1950 . Fig. 4 shows the number of shocks per hour as observed in Tinsukia. The first aftershock of the Assam earthquake was reporter within two minutes after the occurrence of the main shock. Initially the frequency of occurrence was quite high, but after ten hours the frequency starterl falling and the number of shocks per hour reduced to + by $A$ unust 16 at 17 hours. In this case the general trend of decay followed the same inverse power law as given in Eq. [4].

Frequency-Magnitude can be expressed by the relationship $\left({ }^{14}\right)$

$$
\log N=a-b M
$$

where $N$ is the number of earthquakes with magniturles between $M$ and $M+d M$, and $a$ and $b$ are constants.

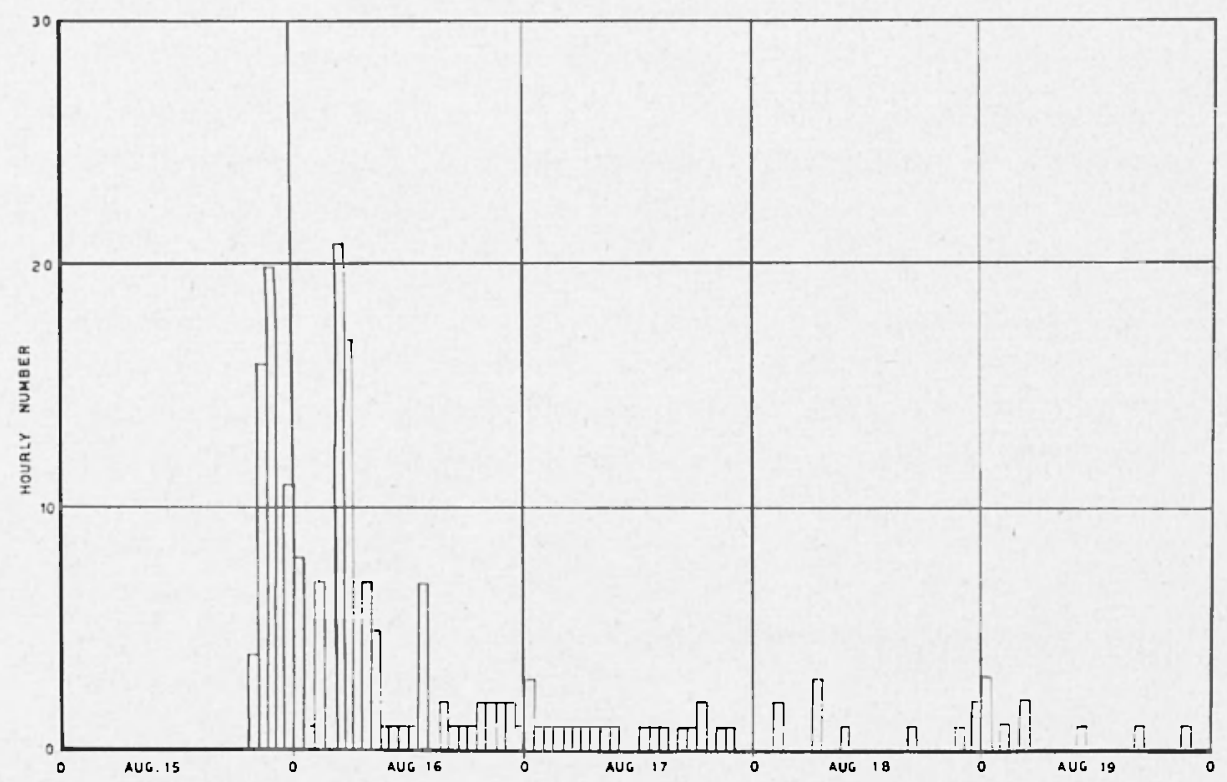

Fig. 4 - Number of shocks per hour against time as observed in Tinsukia from August 15 to August 23, 1950. 
This equation has been widely used by many seismologists, e.g., Suzuki $\left({ }^{27}\right)$, Isacks and Oliver (16), Suyehiro et al. ${ }^{(26)}$, Page (28) and Chouhan (10,11) to study foreshocks, aftershocks and ordinary earthquakes throughout the entire range of observable magnitudes.

Many authors have used a univariate least square procedure to determine the constants $a$ and $b$ in Eq. [5]. However, this approach has certain limitations, such as it tends to bias the estimate of $b$ and underestimates the confidence limits of the estimate. The distribution of the number of events of a certain magnitude is not normal, but tends to be normal only for a very large number of events.

Assuming that every earthquake can be regarded as a random sample from a population whose magnitude distribution takes the form of $\mathrm{Eq}$. [5], Utsu (32,33) has proposed a method for estimating the $b$ values from a given set of Magnitude-Frequency data using the formula.

$$
b=S \log e /\left\{\Sigma M_{i}-S M_{s}\right\}
$$

where $S$ is the total number of earthquakes and $s$ and $i$ are suffixes of $M$ with magnitudes $M_{i} \geqslant M_{8}$, and $\Sigma M_{i}$ is the sum of the magnitudes of all the earthquakes from a given population.

If the magnitude is given at an interval of $\Delta M$, say 0.1 or 0.25 , and the central value for the smallest class is $M_{s}, M_{s}$ should be taken as equal to $\left(M_{s}-\Delta M / 2\right)$. The accuracy of this method was compared with several conventional methods and it was found that Eq. [6] gives most accurate and unbiased $b$ values when $(b \cdot \Delta M)<0.25$. When b. $\Delta M>0.25$, Eq. [6] gives systematically smaller $b$ values, but reduction to the correct value can be made by multiplying by $\eta$, which is a function of $b \cdot \Delta M$.

For the present sequence the $b$ value has been obtained using the relation [6] and applying the correction to restore the correct value by multiplying by $\eta$, as discussed by Utsu ( $\left.{ }^{33}\right)$. The correct value of $b$ for the 1950 aftershock sequence is $0.52 \pm 0.095$. This value of $b$ is quite low, which may be due to incompleteness of the data and to probable errors in the magnitude values, as mentioned earlier. Under the assumption of no uncertainty in the magnitude values, the approximate 95 percent confidence limits for the estimate of $b$ from Eq. [6] are $\pm 1.96 b / \sqrt{n}$, as shown by $A$ ki (1). However, the uncertainties in the magnitude values are in general so large that the confidence limits are very small, such as in the present case, where they are \pm 0.095 . 
$b$ values obtained for the aftershock sequence are in general larger than the $b$ values obtained from the regional seismicity studies, as reported by Mogi $\left({ }^{17}\right)$. However, for the present case this is not valid because of the low value of $b$ reported in this study.

\section{Focal Mechanism}

An equal angle projection $\left({ }^{13}\right)$ of the lower hemisphere of the focal sphere using a Wullf net has been used to study the focal mechanism of the main shock using Tandon's $\left({ }^{30}\right)$ first motion $P$ wave data (Tandon used the extended distance method of Byerly in plotting the data). Values of $i$, the angle of incirlence at the source as measured from the downward vertical for a given distance, are computed from the tables of Hodgson and Storey $\left({ }^{15}\right)$. $\Lambda$ similar method of analysis has been employed by Ritsema (23), using the Wullf net, and by Sykes $\left({ }^{28}\right)$, using a Schmidt net. In Fig. 5 solid circles denote compression and open circles denote rarefaction. The distribution of compression and dilatations defines two planes, one striking almost east-west and dipping steeply northward and the other, which is not well defined, striking north-south and dipping eastwarl at an angle of $62^{\circ}$. None of the readings is inconsistent. The nodal plane striking east-west is well defined and is chosen as the fault plane because of the following geological and field evidence, which precludes the selection of the other nodal plane as the fault plane:

1. Geologically, many longitudinal faults running parallel to the Himalayas are known to exist in this part of the Himalayas. According to Boileau $\left.{ }^{(20}\right)$, a vast tearing movement along the front of the Assam Himalayas caused this earthquake.

2. The isoseismal line, drawn by Poklar (20) after personally studying the field effects, for intensity $X$ on the R.F. scale shows elongation in the east-west direction.

3. Field evidence of the area affected by landslides shows that it has omit almost east-west trend, starting from northern Burma and extencling into northern Assam.

The arrows in Fig. 5 indicate the sense of shear displacement on the plane that was chosen as the fault plane. This fault plane solution shows normal faulting with predominent strike slip motion (right lateral strike slip), the fault plane striking almost in the east-west direction and dipping northward at an angle of $80^{\circ}$. This solution is similar to Tandon's solution $\left({ }^{30}\right)$. 


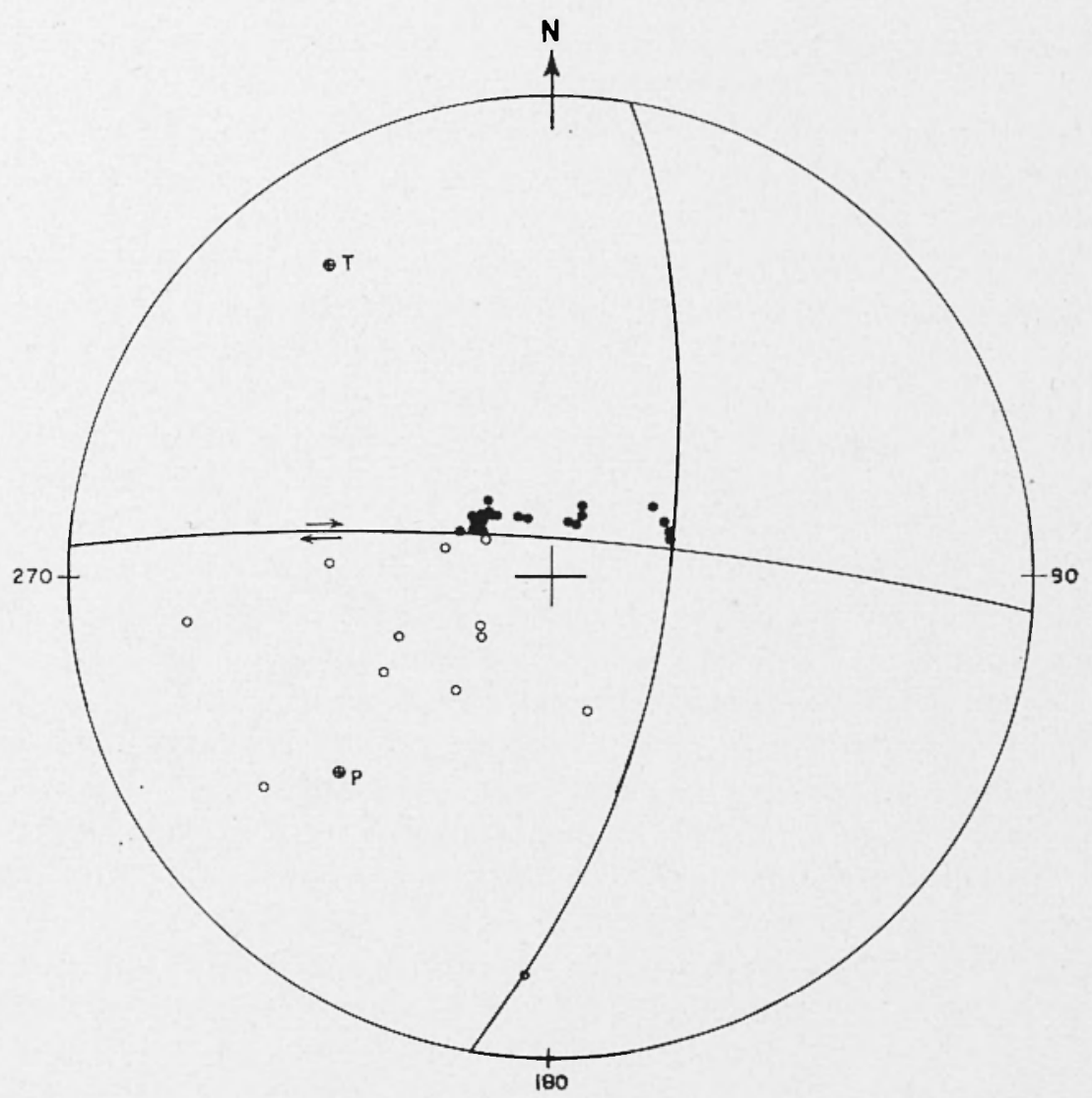

Fig. 5 - Focal mechanism solution of the Assam earthquake of August 15, 1950. Open circles denote dilatations; solid circles denote compressions. $P$ and $T$ denote axes of maximum pressure and maximum tension. Double arrows (reversed in direction) show sense of shear motion along the nodal plane selected as fault plane. (Note the second plane is not uniquely defined in this case).

\section{Spatial Distribution of Aftershocks}

All the epicenters of recorded aftershocks of $M \geqslant 5$ are listed in the $\Lambda$ ppendix and plotted on a map (fig. 6 ). The figure also shows intensity $X$ (R.F. scale) as drawn by Poddar $\left({ }^{20}\right)$ on the basis of field data, and some moderate aftershocks recorded until August 31, 1950 (shown under a separate rectangle, after Tandon $\left({ }^{20}\right)$. The aftershock area is not clearly defined, with the main shock at one end of the aftershock distribution. The spatial distribution of aftershocks is diffuse, 


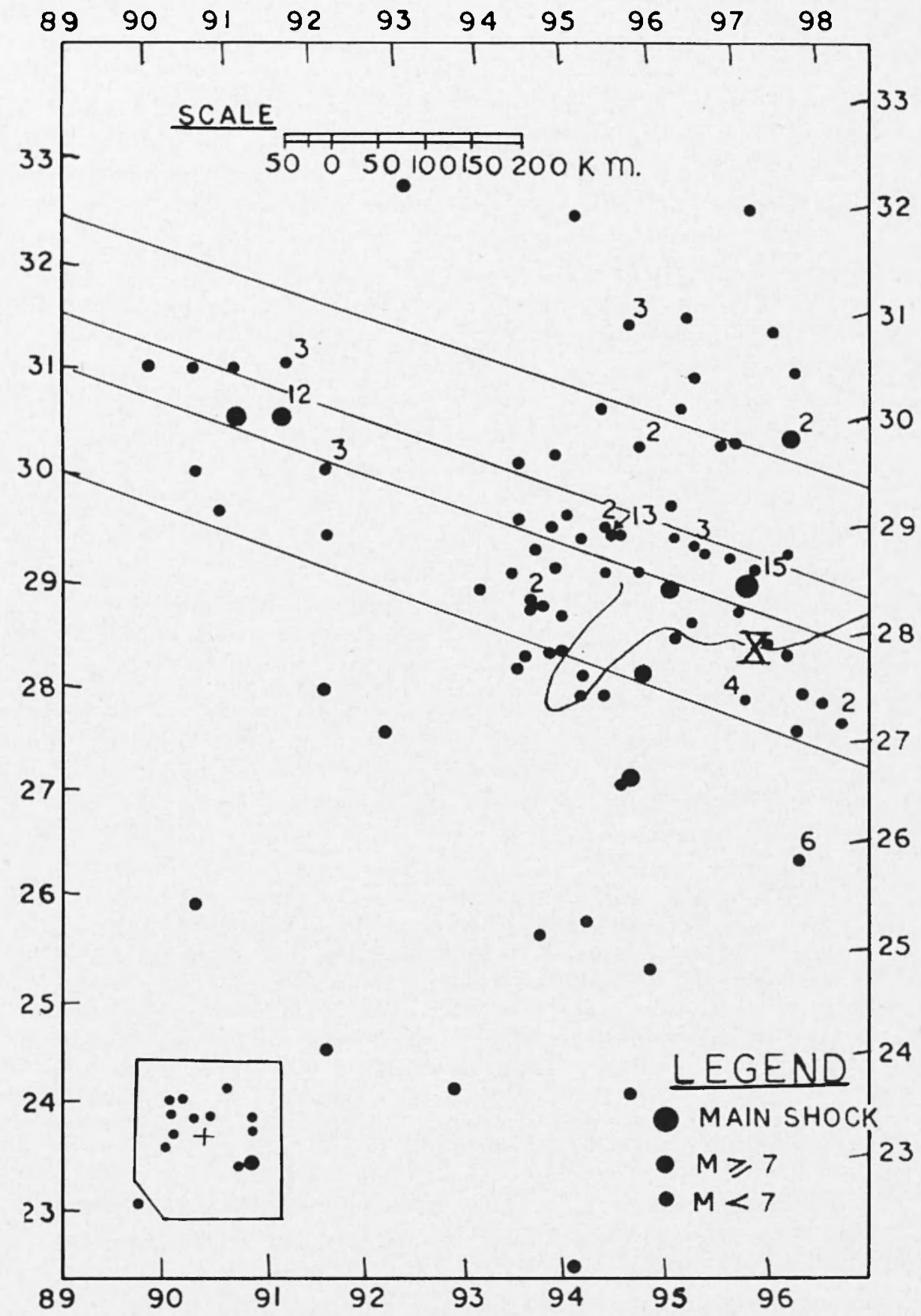

Fig. 6 - Spatial distribution of aftershocks with $U \geqslant 5$. Number against the epicentre indicates total number of events from the same source. The figure also shows R.F. intensity $\mathrm{X}$ after Poddar $\left({ }^{20}\right)$ and epicentres of aftershocks of moderate intensity upto August 31, 1950 shown in a small rectangle, after Tandon $\left({ }^{20}\right)$, extending from $27.5^{\circ} \mathrm{N}$ to $32.5^{\circ} \mathrm{N}$ and $92.5^{\circ} \mathrm{E}$ to $97.5^{\circ} \mathrm{E}$. 
with a prominent scatter of epicenters in the Assam and Tibet regions. This scatter may be clue to poor location of many of the aftershocks, because of poor distribution of seismological observatories in Assam. Neglecting the scatter of the epicenters in Tibet and Assam, which Richter (22) attributes to "transversely aligned seismicity". The spatial distribution shows some alignment of the aftershocks with main centers of activity at the two ends of the fault segment. The rectangular lines trending WNW-ESE, with the fault located at the center are shown in Fig. 6. The fault zone agrees fairly well with the fault plane solution discussed above. The aftershock activity migrated towards the WNW direction from the main shock, the path coinciding with the great Himalayan mountain containing several longitudinal zones separated by faults. Assuming that the aftershock distribution pattern coincides roughly in length with the active fault segment, as observed by Benioff ( ${ }^{8}$ ) in Kern country, faulting was propagated to a distance of about $700 \mathrm{kms}$ in the WNW direction from the main shock. St. Amand $\left(^{25}\right)$ has shown that there are two centers of main aftershock activity at the two ends of the active fault segment in the Kern country sequence of 1952. The only difference between the present sequence and the Kern country sequence is that due to poor location of the aftershocks, the third side of the rectangular distribution of aftershocks is not as well outlined as in the Kern country sequence where 3 sides of the rectangle are fairly well defined. The fault segment defined in Fig. 6 agrees with the major fracture shown by Scheidegger $\left({ }^{24}\right)$.

The epicentres of the aftershocks of the Assam earthquake of June 12, 1897, as reported by Ballore $\left(^{2}\right)$ are reproduced in Fig. 7 . In this case the number of aftershocks is numerous and evenly distributed, with the main shock at the center of the fault zone, which is shown in the figure, coincides fairly well with the Dauki tear fault, a fault with predominent strike-slip motion. This case is very similar to the Kamchatka sequence of 1952 as reported by Bath and Benioff $\left({ }^{5}\right)$.

\section{Conclusion}

1) Strain release in the aftershock sequence shows three linear segments as obtained by Bâth and Benioff $\left({ }^{5}\right)$. The ratio of $B$ values is 1:5:15, because the $B$ value for the first segment is very low as a result of incomplete data in the initial part of the strain release curve. 
A fairly well-defined secondary aftershock sequence shows linear strain recovery, which dies out quickly in comparison to the main sequence.

2) The decay of the hourly frequency of the aftershocks upto 23rd August, 1950 follows an inverse power law, as discussed by Page (18). An estimate of the $b$ value, in the frequency magnitude relation $\log N=a-b M$, made using the maximum likelihood method, is $0.52 \pm 0.095$. The low value of $b$ and also the small range of confidence limits again suggests incompleteness of the data and uncertainties in the magnitude values.

3) The fault plane solution obtained here indicates a normal faulting similar to Tandon's solution ( $\left.{ }^{30}\right)$, with the east-west striking plane as the fault plane, and the footwall moving downward and westward (right lateral strike slip).

4) The spatial distribution of aftershocks shows two main centers of aftershock activity at the two ends of the probable fault, with

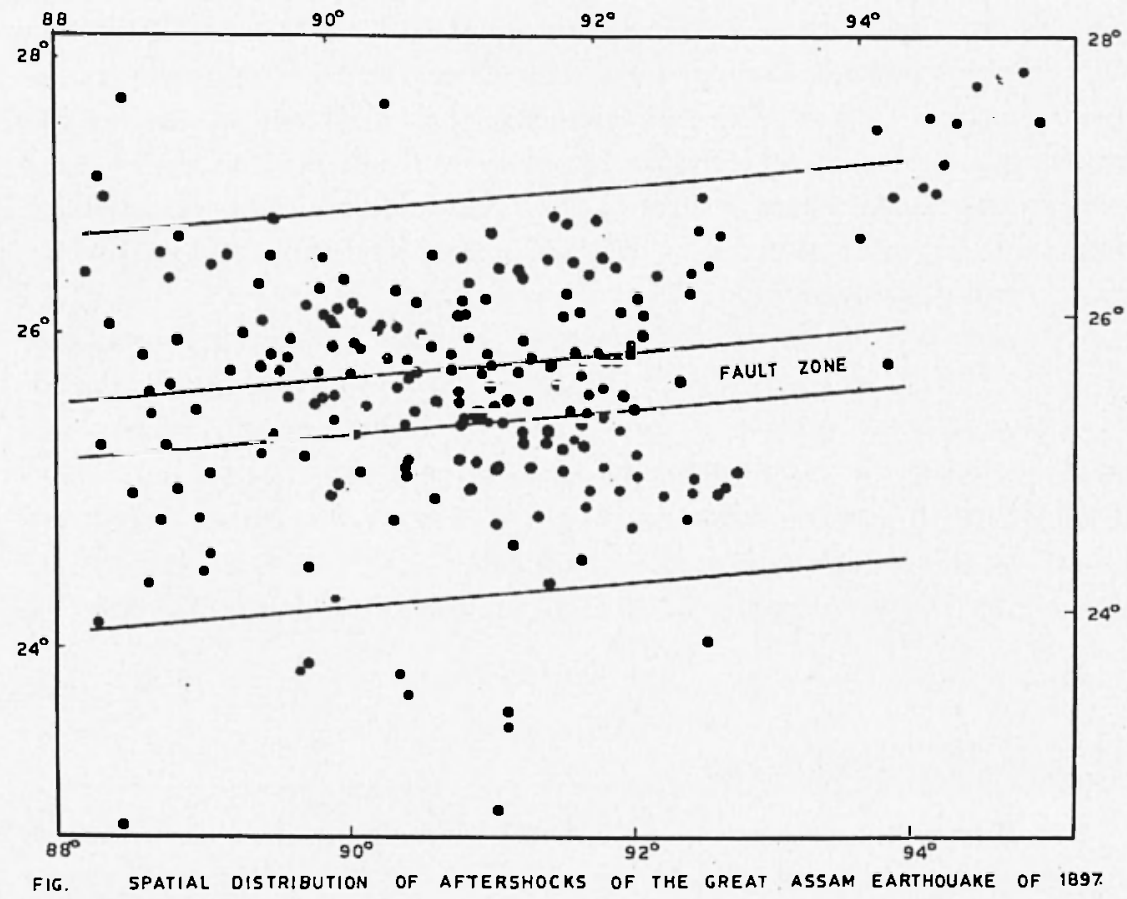

Fig. 7 - Spatial distribution of aftershocks of the great Assam earthquake of June 12, 1897 as reported by Ballore ( $\left.{ }^{2}\right)$. 
the main shock at one end and a late large aftershock at the other end. The faulting movement seems to have propagater in WNT direction to a ristance of $700 \mathrm{~km}$. The probable fault, connecting the two ends of the active centers of the aftershocks, becomes fairly apparent when one takes into account the "transversely aligned seismicity" which explains the scatter of the aftershocks in space. Moreover, it is highly improbable that the magniturle of scatter of the aftershocks of Tibet and Assam earthquakes is causer by the longitudinal faults, which exist in this region Belyaevsky $\left(^{0}\right)$, Barkhatov $\left(^{1}\right)$ and Evans $\left({ }^{12}\right)$.

Appendix I.

List of aftershocks as reported by Tandon $\left({ }^{29}\right)$ and the International Seismological Summary.

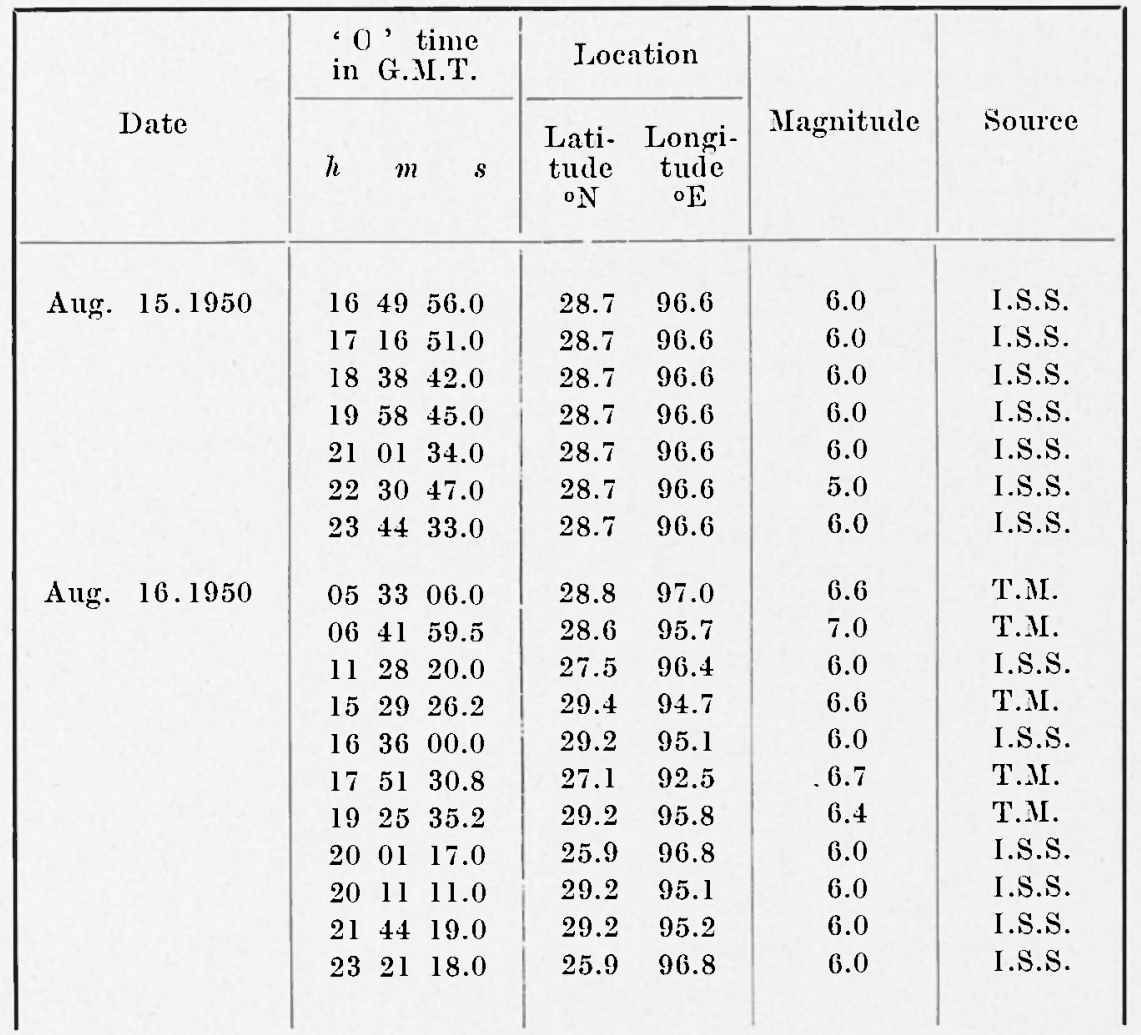




\begin{tabular}{|c|c|c|c|c|c|c|c|}
\hline \multirow{2}{*}{ Jate } & \multicolumn{3}{|c|}{$\begin{array}{l}\text { 'o' time } \\
\text { in G.M.'T. }\end{array}$} & \multicolumn{2}{|c|}{ Location } & \multirow{2}{*}{ Magnitude } & \multirow{2}{*}{ Source } \\
\hline & $h$ & $m$ & $s$ & $\begin{array}{l}\text { Lati- } \\
\text { tude } \\
\text { oN }\end{array}$ & $\begin{array}{l}\text { Longi- } \\
\text { tude } \\
\text { of }\end{array}$ & & \\
\hline Aug. 17.1950 & $\begin{array}{l}01 \\
03 \\
05 \\
08 \\
10 \\
14 \\
23\end{array}$ & $\begin{array}{ll}54 & 1 \\
44 & 1 \\
29 & 1 \\
05 & 0 \\
30 & 3 \\
45 & 5 \\
56 & 3\end{array}$ & $\begin{array}{l}14.0 \\
14.0 \\
13.6 \\
06.0 \\
37.0 \\
55.0 \\
34.0\end{array}$ & $\begin{array}{l}28.9 \\
29.2 \\
29.2 \\
29.2 \\
25.9 \\
25.9 \\
27.9\end{array}$ & $\begin{array}{l}94.5 \\
95.1 \\
94.8 \\
95.1 \\
96.8 \\
96.8 \\
91.9\end{array}$ & $\begin{array}{l}6.5 \\
5.0 \\
6.2 \\
6.0 \\
6.0 \\
6.0 \\
6.0\end{array}$ & $\begin{array}{l}\text { T.AI. } \\
\text { I.S.S. } \\
\text { T.MI. } \\
\text { I.S.S. } \\
\text { I.S.S. } \\
\text { I.S.S. } \\
\text { I.S.S. }\end{array}$ \\
\hline Aug. 18.1950 & $\begin{array}{l}01 \\
11 \\
16 \\
18 \\
22\end{array}$ & $\begin{array}{ll}07 & 5 \\
20 & 2 \\
58 & 4 \\
29 & 5 \\
17 & 3\end{array}$ & $\begin{array}{l}51.2 \\
22.0 \\
48.9 \\
54.0 \\
30.0\end{array}$ & $\begin{array}{l}29.4 \\
29.2 \\
29.9 \\
28.7 \\
28.7\end{array}$ & $\begin{array}{l}95.8 \\
95.1 \\
96.4 \\
96.6 \\
96.6\end{array}$ & $\begin{array}{l}6.5 \\
6.0 \\
6.6 \\
5.0 \\
6.0\end{array}$ & $\begin{array}{l}\text { T.MI. } \\
\text { I.S.S. } \\
\text { T.MI. } \\
\text { I.S.S. } \\
\text { I.S.S. }\end{array}$ \\
\hline Aug. 19.1950 & 21 & 295 & 55.0 & 28.7 & 96.6 & 6.0 & I.S.S. \\
\hline $\operatorname{Lug} .20 .1950$ & $\begin{array}{l}09 \\
10\end{array}$ & $\begin{array}{ll}03 & 3 \\
37 & 1\end{array}$ & $\begin{array}{l}37.0 \\
13.0\end{array}$ & $\begin{array}{l}29.2 \\
29.2\end{array}$ & $\begin{array}{l}94.2 \\
95.1\end{array}$ & $\begin{array}{l}6.4 \\
5.0\end{array}$ & $\begin{array}{l}\text { T.M. } \\
\text { I.S.S. }\end{array}$ \\
\hline Aug. 21.1950 & $\begin{array}{l}05 \\
08 \\
18 \\
22\end{array}$ & $\begin{array}{ll}51 & 2 \\
29 & 3 \\
43 & 5 \\
55 & 3\end{array}$ & $\begin{array}{l}29.8 \\
34.8 \\
53.1 \\
31.3\end{array}$ & $\begin{array}{l}27.5 \\
32.7 \\
29.4 \\
28.8\end{array}$ & $\begin{array}{l}97.0 \\
93.0 \\
94.2 \\
95.4\end{array}$ & $\begin{array}{l}6.1 \\
6.4 \\
6.1 \\
6.2\end{array}$ & $\begin{array}{l}\text { T.M. } \\
\text { T.M. } \\
\text { 'Т.M. } \\
\text { 'Т.M. }\end{array}$ \\
\hline Aug. 22.1950 & $\begin{array}{l}01 \\
02 \\
06 \\
13 \\
17\end{array}$ & $\begin{array}{ll}57 & 2 \\
22 & 3 \\
43 & 1 \\
22 & 2 \\
20 & 1\end{array}$ & $\begin{array}{l}22.0 \\
37.1 \\
10.8 \\
20.1 \\
12.0\end{array}$ & $\begin{array}{l}27.2 \\
30.4 \\
29.3 \\
27.4 \\
29.2\end{array}$ & $\begin{array}{l}97.4 \\
95.2 \\
94.5 \\
97.2 \\
95.1\end{array}$ & $\begin{array}{l}6.0 \\
6.0 \\
6.3 \\
6.3 \\
6.0\end{array}$ & $\begin{array}{l}\text { I.S.S. } \\
\text { 'T.M. } \\
\text { T.M. } \\
\text { T.M. } \\
\text { I.S.S. }\end{array}$ \\
\hline Aug. 23. 1950 & $\begin{array}{l}03 \\
15 \\
18\end{array}$ & $\begin{array}{ll}09 & 1 \\
33 & 5 \\
46 & 5\end{array}$ & $\begin{array}{l}19.0 \\
56.8 \\
58.7\end{array}$ & $\begin{array}{l}29.3 \\
27.2 \\
28.8\end{array}$ & $\begin{array}{l}95.1 \\
96.9 \\
96.4\end{array}$ & $\begin{array}{l}6.3 \\
5.9 \\
6.7\end{array}$ & $\begin{array}{l}\text { T.M. } \\
\text { 'T.M. } \\
\text { 'T.M. }\end{array}$ \\
\hline Aug. 24.1950 & 01 & 274 & 45.6 & 28.3 & 96.4 & 6.3 & 'T.M. \\
\hline Aug. 25.1950 & $\begin{array}{l}08 \\
13 \\
16\end{array}$ & $\begin{array}{ll}14 & 0 \\
03 & 3 \\
57 & 2\end{array}$ & $\begin{array}{l}08.0 \\
30.0 \\
29.0\end{array}$ & $\begin{array}{l}29.2 \\
29.2 \\
27.2\end{array}$ & $\begin{array}{l}95.1 \\
95.1 \\
97.4\end{array}$ & $\begin{array}{l}5.0 \\
6.0 \\
5.0\end{array}$ & $\begin{array}{l}\text { I.S.S. } \\
\text { I.S.S. } \\
\text { I.S.S. }\end{array}$ \\
\hline Aug. 26.1950 & $\begin{array}{l}06 \\
13\end{array}$ & $\begin{array}{ll}33 & 0 \\
54 & 1\end{array}$ & $\begin{array}{l}06.4 \\
18.0\end{array}$ & $\begin{array}{l}26.8 \\
32.0\end{array}$ & $\begin{array}{l}95.1 \\
95.0\end{array}$ & $\begin{array}{l}7.0 \\
5.0\end{array}$ & $\begin{array}{l}\text { 'T.M. } \\
\text { I.S.S. }\end{array}$ \\
\hline Aug. 27.1950 & 11 & 000 & 02.0 & 30.0 & 94.6 & 6.2 & 'T.M. \\
\hline Aug. 29.1950 & 09 & 050 & 04.0 & 29.2 & 95.1 & 6.0 & I.S.S. \\
\hline Aug. 30.1950 & 02 & $2+3$ & 34 & 28.7 & 96.6 & 5.0 & I.S.S. \\
\hline
\end{tabular}


INVESTIGATIONS ON TIIE AFTERSIIOCK SEQUENCE OF TIIE GREAT ETC. 261

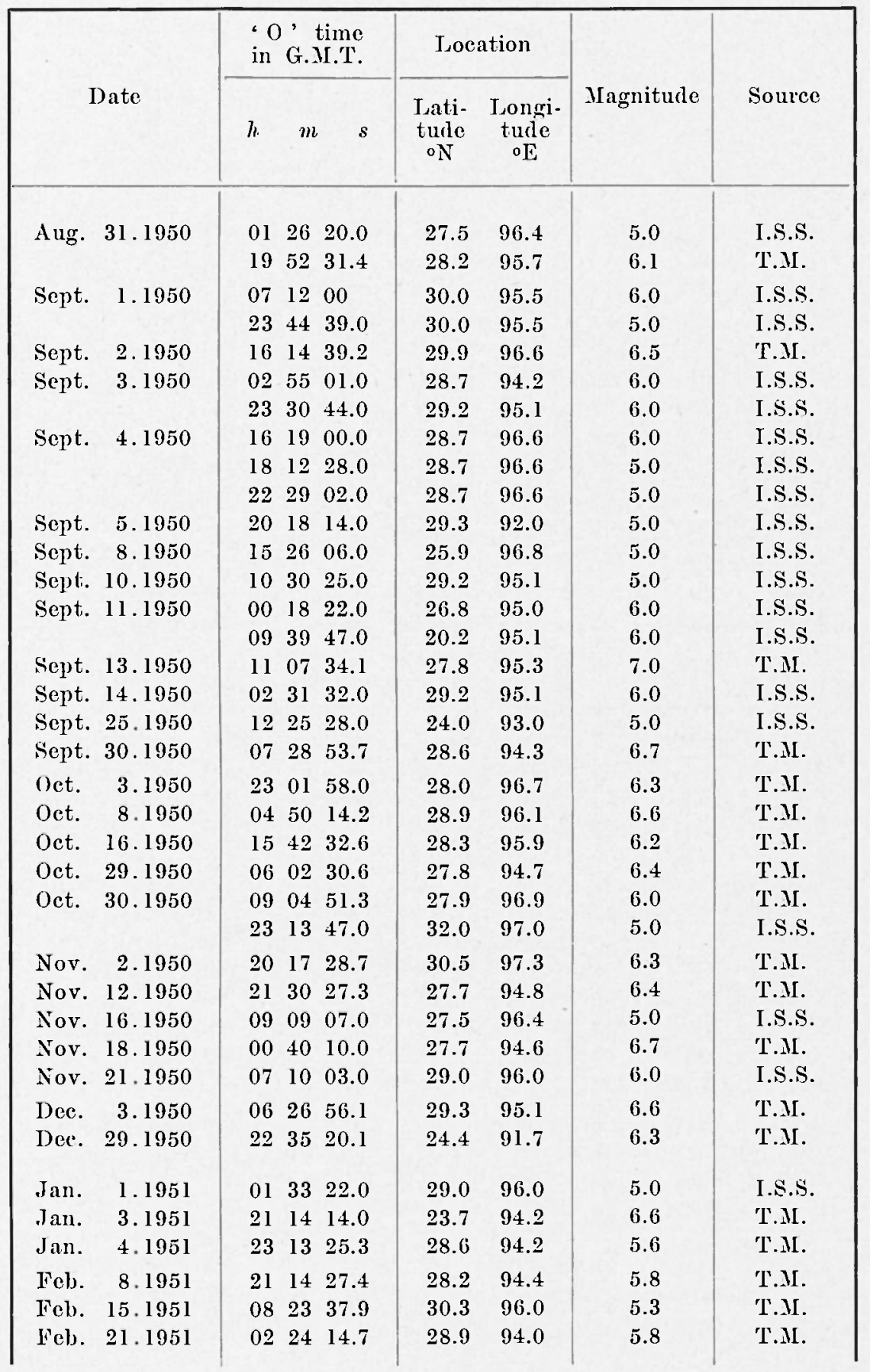




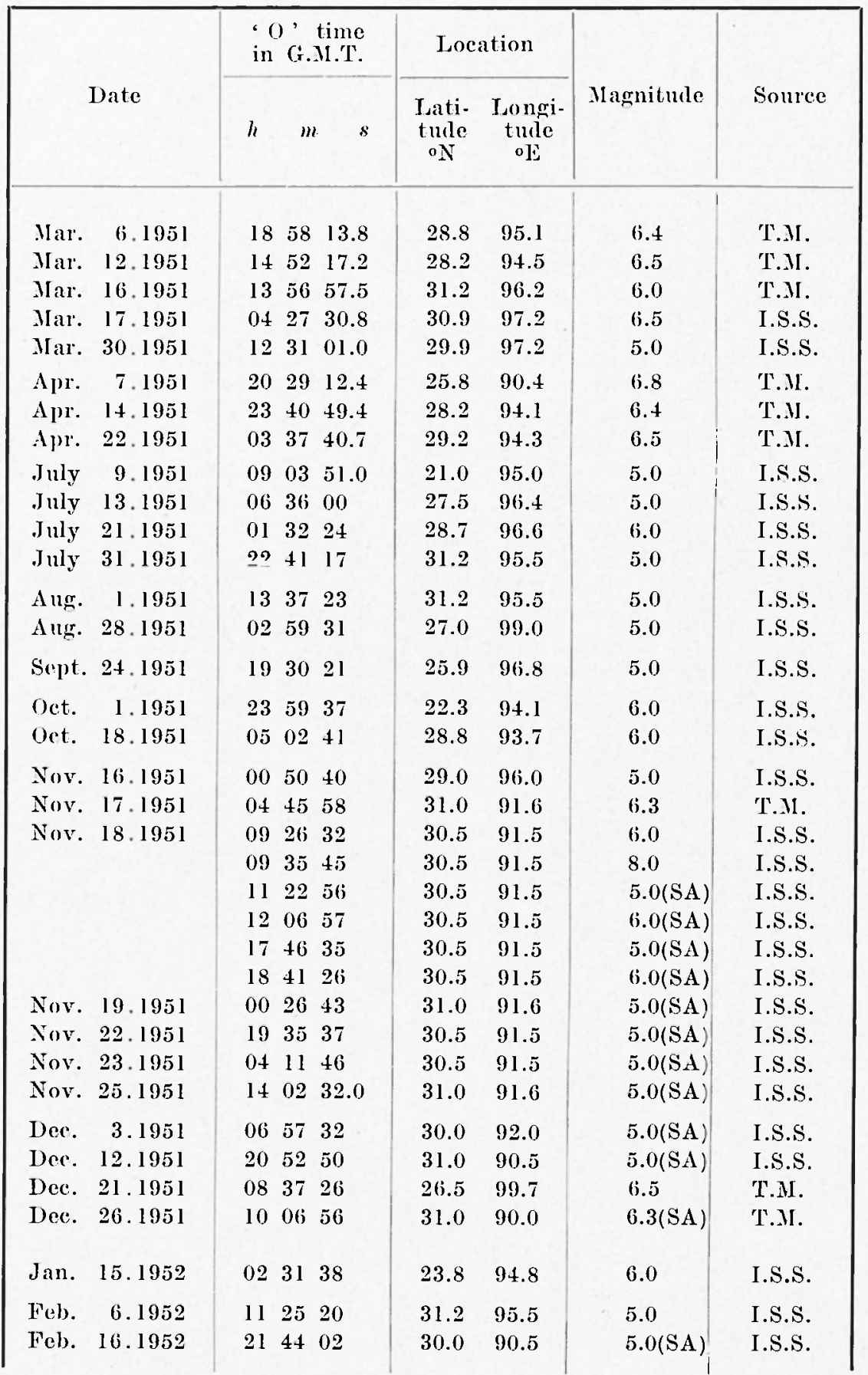


IN VESTIGATIONS ON THE AFTERSHOCK SEQUENCE OF TIL GREAT ETC. 263

\begin{tabular}{|c|c|c|c|c|c|c|c|}
\hline \multirow{2}{*}{ Date } & \multicolumn{3}{|c|}{$\begin{array}{l}\text { 'O' time } \\
\text { in G.E.T. }\end{array}$} & \multicolumn{2}{|c|}{ Location } & \multirow{2}{*}{ Magnitude } & \multirow[b]{2}{*}{ Source } \\
\hline & $h$ & $m$ & $s$ & $\begin{array}{l}\text { Lati- } \\
\text { tude } \\
\text { oN }\end{array}$ & $\begin{array}{c}\text { Longi- } \\
\text { tude } \\
\mathrm{E}^{\mathbf{a}}\end{array}$ & & \\
\hline Mar. $\quad 6.1952$ & 09 & 112 & 23 & 29.6 & 90.8 & $5.0(\mathrm{SA})$ & I.S.S. \\
\hline Mar. 14.1952 & 18 & 194 & & 30.0 & 92.0 & $5.0(\mathrm{SA})$ & I.S.S. \\
\hline Apr. 30.1952 & $\begin{array}{l}00 \\
01\end{array}$ & $\begin{array}{ll}53 & 4 \\
49 & 0\end{array}$ & & $\begin{array}{l}31.0 \\
25.5\end{array}$ & $\begin{array}{l}91.0 \\
94.5\end{array}$ & $\begin{array}{l}5.0(\mathrm{SA}) \\
6.0\end{array}$ & $\begin{array}{l}\text { I.S.S. } \\
\text { I.S.S. }\end{array}$ \\
\hline Мау 26.1952 & 02 & 463 & 32 & 28.5 & 94.5 & 6.0 & I.S.S. \\
\hline June 2.1952 & 10 & 082 & 23 & 30.5 & 91.5 & $6.0(\mathrm{SA})$ & I.S.S. \\
\hline June 2.1952 & 10 & 333 & 34 & 30.5 & 91.5 & $5.0(\mathrm{SA})$ & I.S.S. \\
\hline June 15.1952 & 15 & 155 & 59 & 31.5 & 91.5 & $6.0(\mathrm{SA})$ & I.S.S. \\
\hline June 19.1952 & 12 & 125 & 56 & 22.6 & 99.7 & $7.0(\mathrm{SA})$ & T.M. \\
\hline Aug. 19.1952 & 16 & 020 & 07.0 & 30.5 & 91.0 & 7.5 & Т.М. \\
\hline Aug. 25.1952 & 01 & 4448 & 48.0 & 28.0 & 94.0 & 6.0 & I.S.S. \\
\hline Sept. 15. 1952 & 17 & 5920 & 20.0 & 30.0 & 92.0 & 5.0 & I.S.S. \\
\hline Nov. 7.1952 & 04 & 335 & 57.0 & 25.4 & 94.0 & 6.0 & I.S.S. \\
\hline Nov. 28. 1952 & 05 & $341^{\prime}$ & 17.0 & 25.0 & 95.2 & 6.0 & I.S.S. \\
\hline Apr. 23.1953 & 03 & 505 & 56.0 & 30.5 & 96.2 & 6.0 & I.S.S. \\
\hline Oct. 8.1953 & 16 & 200 & 06.0 & 29.9 & 97.2 & 6.0 & I.S.S. \\
\hline
\end{tabular}

I.S.S. - International Seismological Summary.

T.M. - Magnitude determined by Tandon (1954) using the standard WoodAnderson records of Chatra, New Delhi and Poona Stations.

(SA) - All the magnitudes preceding $S A$ are secondary aftershocks of the largest recorded aftershock which occurred on November 18, 1951 having Richter magnitude 8.0.

\section{ACKNowledgenexts.}

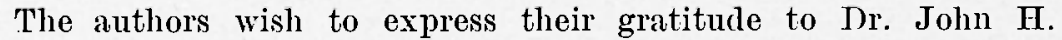
Hodgson of Dominion observatory, Canada and to Dr. G. Purcaru of Romania for their help in sending the literature and to Dr. Tandon and Dr. Jaikrishman for their advice from time to time. 


\section{REFERENCES}

(1) AKI, K., 1965. - Maximum likelihood estimate of $b$ in the formula Log $N=a-b$ II and its confidence limits. "Bull. Earthqu. Res. Inst.", Tokyo Univ., 43, 237-239.

(2) BaLLORE, 1911. - The seismic phenomena in British India and their connections with its geology. Memoir "G.S.I.", 35, 153-179.

(3) BANERJEe S., 1957. - Earthqualies in the IImalayan region. "Indian Association for the Cultivation of Science", Calcutta.

(') Barkinatov B., 1963. - Tectonies of the Pamirs (in Russian). "University of Leningrad", Leningrad.

${ }^{5}$ ) BATH M. and BENiofF H., 1958. - The aftershock sequence of Kamchatka earthquake of Nov. 4, 1952. "Bull. Seis. Soc. Am.", 48, 1-15.

${ }^{(8)}$ Belyanskr, N., 1966. - Principle geological features of the Karaloram. "Int. Geol. Rev.", 8, 127-142.

(") BeniofF H., 1951 a. - Earthquakes and Rock ereep. "Bull. Seis. Soc. Am.", 41, 31-62.

( $\left.{ }^{8}\right)$ BeNIOFF, II., 1955 b. - Mechanism and Strain characteristics of the white wolf fault as indicated by aftershock sequence. "Calif. div. mines. Bull.", 171, $199-202$.

(") Choulian, R., Gaur, V. and Mithal, R., 1966. - Seismicily of Assam. "Third symposium on earthquake Engg., U.O.R., Roorkee", 423-430.

(10) Cinounan, R., 1968. - Studies of seismicity of India and an analysis of some strong earthquake sequences. Ph. 1). thesis (unpublished), 'University of Roorkee'.

(11) Chouliax, R., 1970. - A note on the frequency magnitude relation $\log N=$ $a-b .3$. "Jl. Pure and Appl. Geophysies", 81, 119-123.

(12) Evans P., 1964. - The tectonic framework of Assam. "Jour. Geol. Soc.", India, 5, 80-96.

(13) Friemax, M., 1964. - Petrojabric techniques for the determination of Principal stress directions in rocks. State of stress in the earth's crust Edited by W. R. Judd., "American Elsevier Publ. Co. New York", pp. 451-552.

(14) Gutenberg, B. and Riciter, C. F., 1954. - Seismicity of the Earth and its Associated phenomena. "Princeton Univ. Press".

(15) Hodgsox, J. and Storex, R., 1953. - Tables extending Byerly's jault plane technique to earthquake of any focal depth. "Bull. Seis. Soc. Am.", $43,49-61$. 
INVESTIGATIONS ON TIE AFTERSIOCK SEQUENCE OF TIE GREAT ETC. 265

(18) IsAcks, B. and OLIver, J., 1964. - Seismic waves with frequencies from. 1 to 100 cycles per second recorded in a deep mine in northern New Jerscy. "Bull. Seis. Soc. Am.", 54, $1941-1979$.

(17) Mogi K., 1963. - The fracture of a semi-infinite body caused by an inner stress origin and its relation to the earthquake phenomena (2nd paper). "Bull. Earthq. Res. Inst.", Tokyo Univ., 41, 595-614.

(18) PAGE, R., 1968. - Aftershocks and microaftershocks of the great Alaska Earthquake of 1561. "Bull. Scis. Soc. Am.", 57, 1131.1168.

(19) Purcaru, G., 1972. - On the Statistical interpretation of Bath's law. Paper presented at the meeting of European Commission on Scismology, Brasov, on September 5, 1972, p. $\mathrm{D}_{4}$.

(20) RAO, M., 1953. - Compilation of papers on Assam earthquake of 1950. "Central Board of Geophysics Publication", 1, Calcutta.

(21) RICHTER, C., 1958. - Elementary Seismology. "W. H. Freeman \& Co.", San Francisco.

(22) RiCIITER, C., 1969. - Transversely aligned seismicity and concealed structures. "Science", American Assoc. for the Advancement of Science, 166, 173-178.

${ }^{(23)}$ Ritseira, R., 1955. - The fault plane technique and the mechanism in the focus of 'Hindukush earthqualies'. "Ind. J. Met. Geoph.", 6, 1-10.

(2.) Scheidegger, A., 1960. - The tectonics of central Asia in the light of earthquake fault plane solutions. A symposium on earthquake mechanism, edited by John H. Hodgson, 'Publication of Dominion Observatory, Ottawa, Canada', XXIV, 10, 385-388.

(25) St. Amand P., 1956. - Two proposed measures of seismicity. "Bull. Seis. Soc. Am.", 46, 41-45.

$\left({ }^{26}\right)$ Suyeniro, S., ASADA, T. and OITAKe, M., 1964, - Foreshocles and aftershocks accompanying a perceptible earthquale in Central Japan. "Papers, Meteorol. Geophys." Tokyo, 15, 71-88.

${ }^{(27)}$ SUzuKi Z., 1959. - A statistical study on the occurrence of small earthquakes (chapters 4-10). "Sci. Rept. Tohoku Univ. Ser.", 5, "Geophys.", 15, 10-54.

${ }^{(28)}$ SYKEs, 1967. - Mechanism of earthquales and nature of faulting on the ILid Oceanic ridges. "Jl. Gcoph. Res.", 72, 2131-2153.

${ }^{(29)}$ Tandon, A. N., 1954. - The study of the great Assam earlhquale of August, 1950. "Ind. J. Met. Geoph.", 5, 95-137.

$\left({ }^{30}\right)$ Tandon A. N., 1955. - Direction of faulting in the great Assam earth. quake of 15th August, 1950. 6, 61-64.

(31) UTsu, 'T., 1961. - A statistical study on the occurrence of aftershocks. "Geophys. mag.", 30, 521-605. 
(32) UTsu. T., 1965. - A method for determining the value of b in a formula Log $N=a-b . I I$ showing the magnitude - frequency relation for earth. quales (in Japanese with English abstract). "Geophys. Bull. Hokkaido Univ", 13, 99-103.

${ }^{(33)}$ U.ssu, T., 1967. - Some problems of the frequency distribution of earthquakes in respect to magnitude. "Geophys. Bull. Hokkaido Univ.", 17, p). 53-59 (in Japanese with English abstract).

${ }^{(34)}$ Vere-Jones, D., 1969. - A note on the statistical interpretation of Bath's law. "Bull. Seis. Soc. Am.", 59, $1535-1541$. 